\title{
Megalopodidae (Insecta, Coleoptera): new occurrence and host plant records for Brazil
}

\author{
Daniela Machado da Rosa Morais'; Geovanni Miguel Rodríguez-Mirón² \& Adelita Maria Linzmeier
}

1 Universidade Federal da Grande Dourados (UFGD), Faculdade de Ciências Biológicas e Ambientais (FCBA), Programa de Pós-Graduação em Entomologia e Conservação da Biodiversidade (PPGECB). Dourados, MS, Brasil. ORCID: http://orcid.org/0000-0002-1348-7976. E-mail: danierosaa@gmail.com

2 Universidad Nacional Autónoma de México (UNAM), Facultad de Estudios Superiores Zaragoza, Museo de Zoología "Alfonso L. Herrera”, Colección Coleopterológica. México, D.F., México. ORCID: http://orcid.org/0000-0003-0751-4672.E-mail: ge020araa@yahoo.com.mx

3 Universidade Federal da Fronteira Sul (UFFS). Realeza, PR, Brasil.

ORCID: http://orcid.org/0000-0002-2979-8728. E-mail: adelita.linzmeier@uffs.edu.br

\begin{abstract}
The Brazilian Megalopodidae fauna consists of 147 species from 11 genera, of which Mastostethus Lacordaire is the most diverse, representing about half of the species. Nevertheless, knowledge about species distributions and their relationships with host plants is still scarce. Since this group has endophytic immatures and bore into branches, they are economically important as they mainly damage Solanaceae species. Thus, this study sought to determine the Megalopodidae species that occur in forest fragments of southwestern and western Paraná and associate them with their host plants. For this purpose, we used material collected with Malaise traps and active manual sampling to determine associations with host plants. A total of 170 specimens of 11 species were sampled, of which Pseudhomalopterus carinatus Pic, 1920 was the most abundant and collected in all fragments. Four species were sampled exclusively through manual collections and associated with their host plants, all of which were new association records for Brazilian megalopodides. Mastostethus pantherinus Lacordaire, 1845 was associated with an Asteraceae for the first time. Additionally, Mastostethus minutus Monrós, 1947 is a new record for Brazil.
\end{abstract}

Keywords. Biodiversity survey; Solanaceae; Asteraceae; Megalopodinae; New occurrence.

\section{INTRODUCTION}

Megalopodidae (Coleoptera) has just over 600 species allocated in 30 genera belonging to the subfamilies Megalopodinae, Palophaginae and Zeugophorinae (Erber \& Medvedev, 2002; Rodríguez-Mirón, 2018). Megalopodinae contains about $80 \%$ of the species, presenting the highest diversity in the Ethiopian and Neotropical regions (Rodríguez-Mirón, 2018). In Brazil, 147 species belonging to 10 genera have been recorded, and Mastostethus Lacordaire, 1845 is the most diverse genus with 79 species (Botero, 2018).

Megalopodidae are associated with a wide variety of host plants, including families as Solanaceae, Asteraceae, Euphorbiaceae, Oleaceae, and Fabaceae (Jolivet, 1988; Lawrence \& Slipinski, 2014). Despite this, host plants are known for few species, and in South America, Megalopodinae are most associated with Solanaceae (RodríguezMirón, 2018). This group is economically important because its members are phytophagous with endophytic larvae that feed on internal tissues of branches and stems (Lawrence \& Slipinski, 2014).
For example, some studies consider Agathomerus (Euagathomerus) sellatus (Germar, 1823) and A. (Agathomeroides) flavomaculatus (Klug, 1845) as secondary pests of tomatoes, scarlet eggplant, and peppers, mainly damaging leaves, stems, and shoots (Tella, 1952; Lima, 1955; Vernalha et al., 1968; Santos, 1981; Picanço et al., 1999; Almeida et al., 2009; Modolon et al., 2013).

Thus far, information about Megalopodidae fauna in Brazil has been scarce, both in terms of species diversity, distribution, and relationships to host plants and bioecological information. Given the lack of research about this taxon, the groups' potential economic interest due to the damage it causes to Solanaceae plants and considering there are no records of this group in southwestern Paraná, this work is important because it provides new information about Megalopodidae fauna in a region that has been suffering greatly from anthropic pressures. Thus, the aim of this study was to record the Megalopodidae species that occur in forest fragments in southwestern and western Paraná, seeking to associate them with their host plants. 


\section{MATERIAL AND METHODS}

The material was collected from four forest fragments, three of which were found in southwestern Paraná, in the municipalities of Planalto, Realeza and Santa Izabel do Oeste and one in Céu Azul in western Paraná. The forest fragments are located in Montane and Submontane Mixed Ombrophilous phytogeographic formation. However, the Céu Azul fragment is in Montane Semideciduous Seasonal Forest phytogeographic formation (ITCG, 2009). More information about these fragments can be found in Rech \& Linzmeier (2019).

Two Malaise traps (Townes, 1972) were installed in each fragment, except for the Santa Izabel do Oeste fragment, where only one trap was installed. Weekly samples were carried out from October 2016 to March 2017 (Realeza, Planalto, and Sta Izabel do Oeste) and from September 2017 to March 2018 (Realeza, Planalto, and Céu Azul).

In order to identify host plants, manual samplings were carried out in the Planalto fragment weekly from September to December 2017. Plants were inspected for megalopodides, and when found, they were observed, photographed, and collected. Plant parts (flowers, stems, and leaves) were photographed and collected to make exsiccates (Fidalgo \& Bononi, 1989). Insect-plant associations were only considered when the megalopodid was observed feeding on some plant parts. All observations were made in the field.

For Megalopodinae identification, the Monrós identification key (1947) was used. Also was carried out by means of the comparison with reference material and in some cases with the type specimen of the species deposited in: The Natural History Museum, London, U.K., National Museum of Natural History, Smithsonian Institution, Washington, D.C. USA, and Muséum National d'Histoire Naturelle, Paris, France. The plants were identified using the Herbário Virtual - REFLORA, Flora do Brasil 2020 (REFLORA, 2020) and Flora Digital (Giehl, 2020). The insects are deposited in the Coleção Entomologica UFFS-RE at Universidade Federal da Fronteira Sul, Campus Realeza, PR, and the exsiccates in the Herbário REAL at the same institution.

\section{RESULTS AND DISCUSSION}

In total, 170 Megalopodidae specimens belonging to 11 species of the genera Mastostethus Lacordaire, 1845, Agathomerus Lacordaire, 1845, Megalopus Fabricius, 1801 and Pseudhomalopterus Pic, 1920 were collected, with Mastostethus presenting the highest richness: five species (Table 1, Fig. 1). The most abundant species was Pseudhomalopterus carinatus Pic, 1920, with 78 specimens, followed by Mastostethus lateritius (Klug, 1834) with 31 specimens, both sampled in all fragments, and Megalopus tabidus Klug, 1834 with 26 individuals. The remaining species were less abundant and did not exceed nine individuals (Table 1).

All genera collected are exclusively Neotropical. The genera Mastostethus, Agathomerus, and Megalopus are widely distributed from Argentina to Mexico (RodríguezMirón et al., 2017; Rodríguez-Mirón, 2018). For Brazil, Mastostethus is the genus with the highest number of species, with 79 registered names, followed by Agathomerus with 33 species and Megalopus with 26 species (Botero, 2018). Pseudhomalopterus is a monotypic genus only registered in this country (Botero, 2018; Rodríguez-Mirón, 2018). Except for the Agathomerus species and M. pantherinus Lacordaire, 1845, all species recognized in this study are new records to the state of Paraná. Mastostethus minutus Monrós, 1947, previously known only to Argentina, is also a new record to Brazil, increasing the number of Brazilian Megalopodidae species to 148.

Seven species were exclusively sampled with malaise traps and four species through manual collections (Table 1). Thus, none of the species sampled with Malaise were observed in the field, and although those species were most abundant and occurred in all fragments, it was not possible to determine their host plants. However, for the first time, more precise distribution data is provided for these species.

Adults of Agathomerus (A.) flavomaculatus (Fig. 2C) and Agathomerus (E.) elegans (Klug, 1834) (Fig. 2A) were observed feeding on Solanum (cf., Solanum variabile Mart.) (Solanaceae) flowers. According to Lima (1955), the larvae of $A$. (A.) flavomaculatus drill holes in the stem bases and adults feed on leaves and flowers. Additionally,

Table 1. Species of Megalopodinae (Megalopodidae) collected from forest fragments in southwestern and western Paraná and their abundance in each sampled forest fragment. Note: ${ }^{*}$ species collected with Malaise; ${ }^{* *}$ manually sampled species.

\begin{tabular}{|c|c|c|c|c|c|}
\hline Species & Planalto (N) & Realeza (N) & Céu Azul (N) & Santa Izabel do Oeste (N) & Total \\
\hline Agathomerus (Agathomeroides) flavomaculatus (Klug, 1845)** & 5 & - & - & - & 5 \\
\hline Agathomerus (Euagathomerus) elegans (Klug, 1834)** & 5 & - & - & - & 5 \\
\hline Agathomerus (Euagathomerus) sellatus (Germar, 1823)** & 2 & - & - & - & 2 \\
\hline Pseudhomalopterus carinatus Pic, 1920* & 15 & 44 & 15 & 4 & 78 \\
\hline Mastostethus alternans (Klug, 1834)* & - & 1 & - & 1 & 2 \\
\hline Mastostethus minutus Monrós, $1947^{*}$ & 1 & - & 1 & 1 & 3 \\
\hline Mastostethus pantherinus Lacordaire, $1845^{* *}$ & 1 & - & - & - & 1 \\
\hline Mastostethus lateritius (Klug, 1834)* & 11 & 14 & 5 & 1 & 31 \\
\hline Mastostethus sobrinus Lacordaire, $1845^{*}$ & 5 & - & 4 & - & 9 \\
\hline Megalopus tabidus Klug, $1834^{*}$ & 8 & - & 18 & - & 26 \\
\hline Megalopus waterhousei Baly, $1859^{*}$ & 1 & - & 6 & 1 & 8 \\
\hline Total & 54 & 59 & 49 & 8 & 170 \\
\hline
\end{tabular}


A. (A.) flavomaculatus was one of the most abundant species associated with the scarlet eggplant plant (Solanum gilo Raddi) where its larvae were found boring into the branch bases (Picanço et al., 1999). This species is widely distributed in Brazil and has been recorded in the states of Goiás, Minas Gerais, Espírito Santo, Rio de Janeiro, and from São Paulo to Rio Grande do Sul, in addition to Paraguay and Argentina (Carvalho \& Monné, 2006).
A

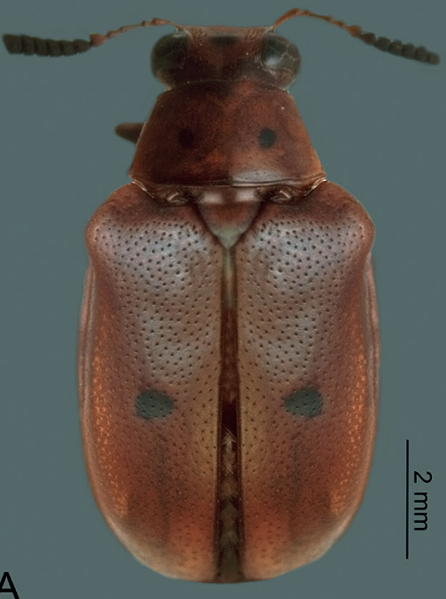

B

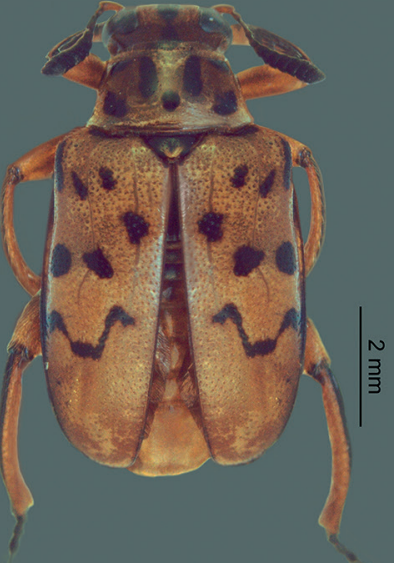

C

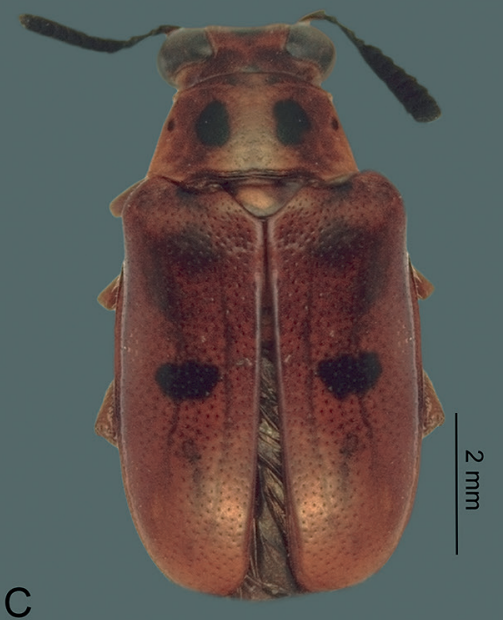

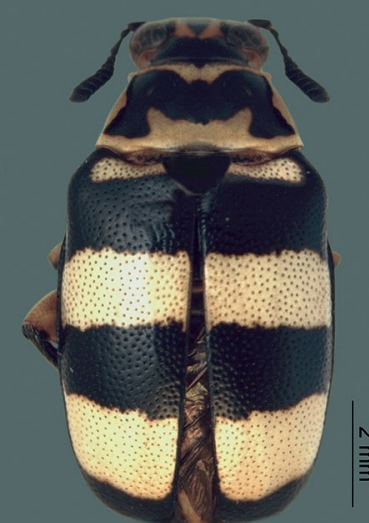

D

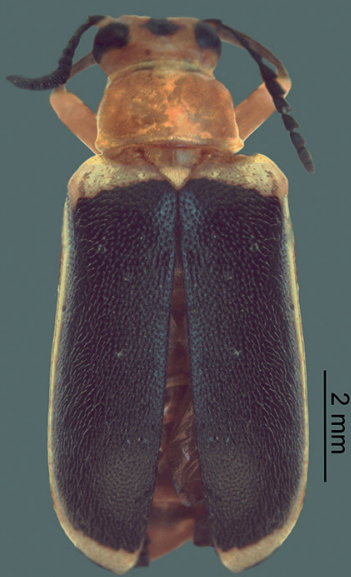

$\mathrm{H}$

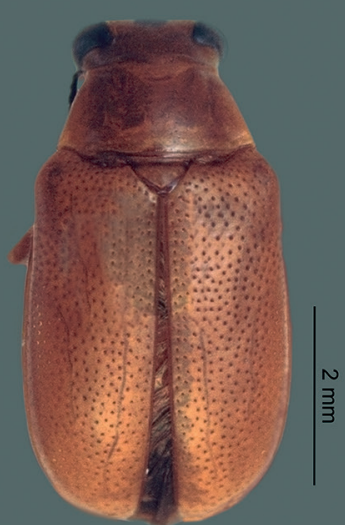

E

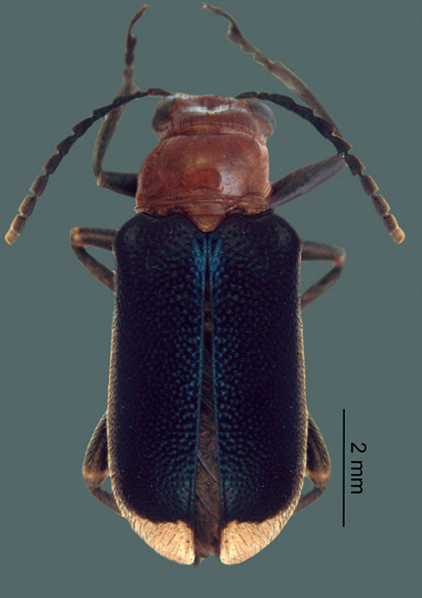

।

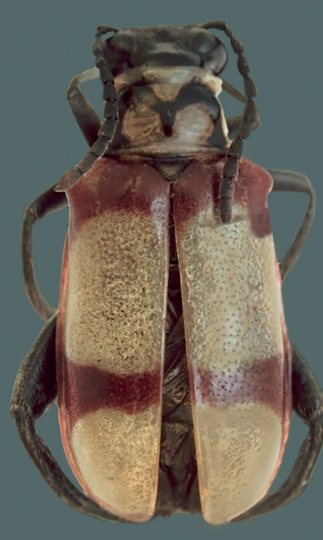

J

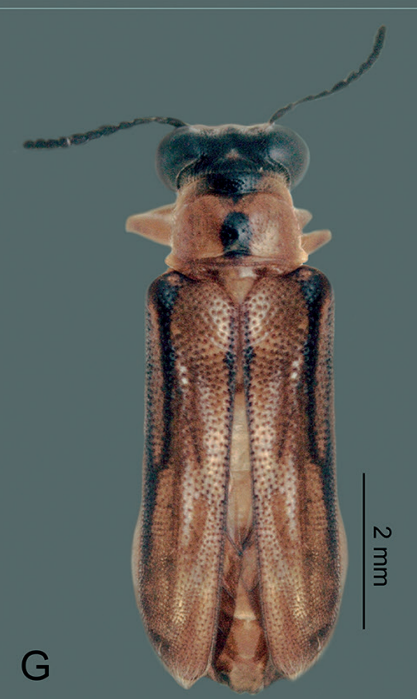

$\mathrm{F}$

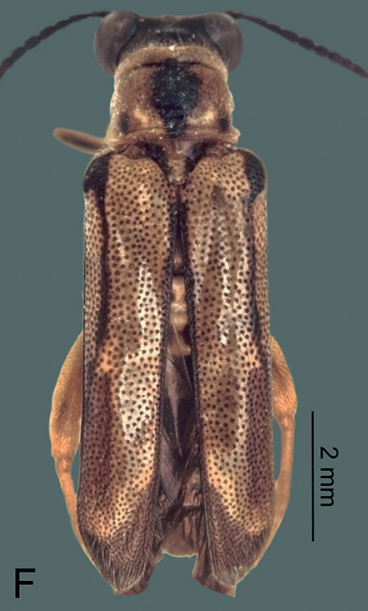

G

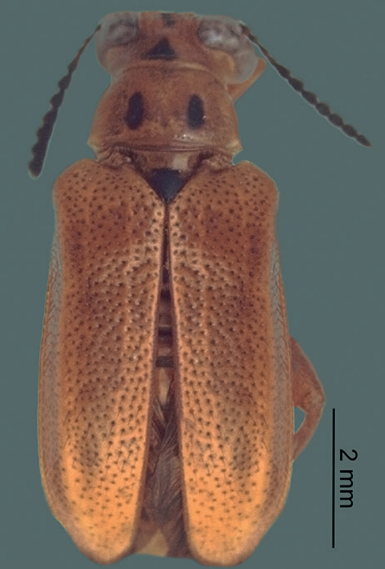

K

Figure 1. Species of Megalopodinae (Megalopodidae) sampled from forest fragments in southwestern and western Paraná. (A) Mastostethus sobrinus Lacordaire, 1845; (B) Mastostethus pantherinus Lacordaire, 1845; (C) Mastostethus lateritius (Klug, 1834); (D) Mastostethus alternans (Klug, 1834); (E) Mastostethus minutus Monrós, 1947; (F) Megalopus tabidus Klug, 1834; (G) Megalopus waterhousei Baly, 1859; (H) Agathomerus (Euagathomerus) sellatus (Germar, 1823); (I) Agathomerus (Euagathomerus) elegans (Klug, 1834); (J) Agathomerus (Agathomeroides) flavomaculatus (Klug, 1845); (K) Pseudhomalopterus carinatus Pic, 1920. 
Adults of Agathomerus (Eugathomerus) sellatus were recorded feeding on Solanum betaceum Cav. (Solanaceae) (Fig. 2D). The adults fed abaxially on the petiole, at the base of leaves that had withered. Inside the branch where the plant was damaged, there was a single white egg. Similar observations were made by Tella (1952) and Santos (1981), who reported aspects of this species' biology in tomatoes (Lycopersicum esculentum Mill.). Such association with tomato has been reported by several authors (Table 2) and, although $A$. (E.) sellatus has not yet been reported as a regular pest of tomato crops, it has frequently been found on conventional crops and is considered an emerging pest (Bavaresco \& Pilati, 2005). Agathomerus (E.) sellatus has also been recorded damaging potato (Solanum tuberosum L.), eggplant (Solanum melongena L.), and chayote (Sechium edule S.) (Tella, 1952; Vernalha et al., 1968). However, in Vernalha et al.'s (1968) paper the image illustrating the species (on page 116) is not actually Agathomerus sellatus, but Cacoselis sp. (Chrysomelidae, Galerucinae, Alticini), a genus associated with passion fruit (Lima, 1955).

Mastostethus pantherinus Lacordaire, 1845 was observed in Vernonanthura, (cf., Vernonanthura tweedie- na ((Baker) H. Rob. (Asteraceae)) (Fig. 2B). The captured specimen was found consuming the stem base. This species was also found feeding on the flowers of the same species of Solanum sp. registered for A. (A.) flavomaculatus. There are records of Mastostethus in plants of the families Bignoniaceae, Verbenaceae, Euphorbiaceae, and Amaranthaceae (Jolivet, 1988; Lawrence \& Slipinski, 2014). In Brazil, there are no records of host plants for this species. Thus, herein we present records of two new host plants for M. pantherinus, along with its association with Asteraceae for the first time.

Considering the records of host plants for Brazilian megalopodides (Table 2), it is possible to affirm that all host plant associations observed in this study are new records for the species.

Thus, it was possible to recognize eleven species in four genera of Megalopodidae that occur in the southwestern and western regions of Paraná, one of which is a new record for Brazil - Mastostethus minutus. In addition, we found new Megalopodinae associations with host plants, demonstrating that there is still much to be investigated, with Asteraceae being recorded for the first time for
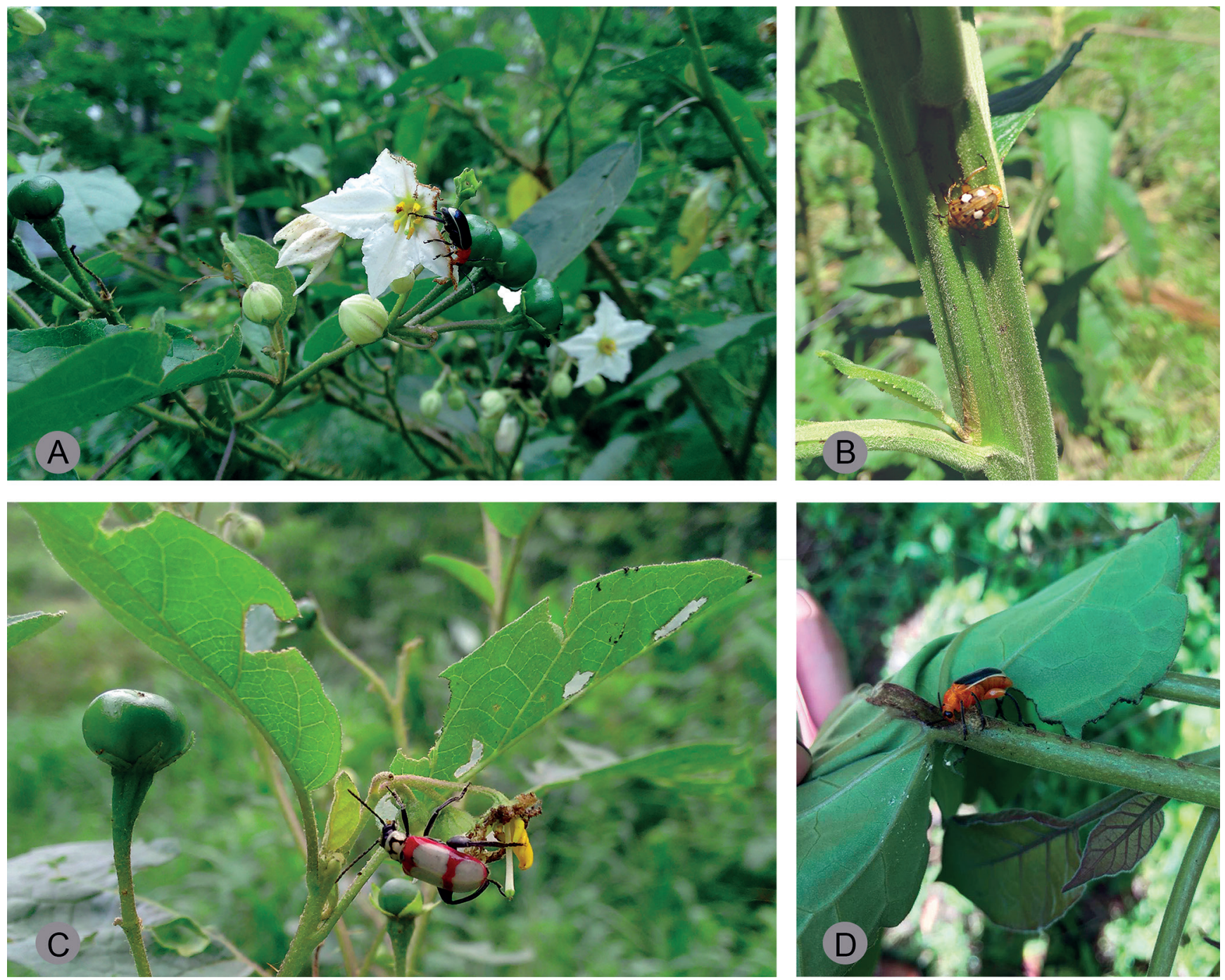

Figure 2. Species of Megalopodinae (Megalopodidae) on its host plants, registered in southwestern Paraná. (A) Agathomerus (E.) elegans feeding on Solanum (cf., S. variabile) (Solanaceae); (B) Mastostethus pantherinus feeding on Vernonanthura (cf., V. tweediena) (Asteraceae); (C) Agathomerus (A.) flavomaculatus feeding on Solanum (cf., S. variabile) (Solanaceae); (D) Agathomerus (E.) sellatus feeding on Solanum betaceum (Solanaceae). 
Table 2. Records of host plants for Megalopodidae that occur in Brazil, available in the literature and registered in this study.

\begin{tabular}{|c|c|c|c|}
\hline $\begin{array}{l}\text { Megalopodidae } \\
\text { species }\end{array}$ & Host plant & $\begin{array}{l}\text { Associated } \\
\text { family plant }\end{array}$ & References \\
\hline Agathomerus sp. & Adenostemma sp. & Asteraceae & Jolivet, 1988 \\
\hline \multirow{6}{*}{$\begin{array}{l}\text { Agathomerus } \\
\text { (E.) sellatus }\end{array}$} & Lycopersicum esculentum & Solanaceae & $\begin{array}{l}\text { Tella, } 1952 \\
\text { Modolon et al., } 2013 \\
\text { Bavaresco \& Pilati, } 2005 \\
\text { Vernalha et al., } 1968 \\
\text { Jolivet, } 1977\end{array}$ \\
\hline & Solanum melongena & Solanaceae & Vernalha et al., 1968 \\
\hline & Solanum tuberosum L. & Solanacea & $\begin{array}{l}\text { Tella, } 1952 \\
\text { Vernalha et al., } 1968\end{array}$ \\
\hline & Sechium edules. & Cucurbitaceae & Vernalha et al., 1968 \\
\hline & Solanum sp. (juá) & Solanaceae & Silva et al., 1968 \\
\hline & Solanum betaceum & Solanaceae & In this study \\
\hline \multirow{4}{*}{$\begin{array}{l}\text { Agathomerus } \\
\text { (A.) flavomaculatus }\end{array}$} & Alternanthera sp. & Amaranthaceae & Lima, 1955 \\
\hline & Capsicum baccatum L. & Solanaceae & $\begin{array}{l}\text { Carvalho \& Moné, } 2006 \\
\text { Jolivet, } 1977\end{array}$ \\
\hline & Solanum gilo $\mathrm{R}$ & Solanaceae & Picanço et al., 1999 \\
\hline & Solanum (cf., S. variabile) & Solanaceae & In this study \\
\hline $\begin{array}{l}\text { Agathomerus } \\
\text { (E.) elegans }\end{array}$ & Solanum (cf., S. variabile) & Solanaceae & In this study \\
\hline \multirow[b]{2}{*}{ Mastostethus spp. } & \multirow[b]{2}{*}{ Alternanthera sp. } & Amaranthaceae & Lawrence \& Slipinski, 2014 \\
\hline & & $\begin{array}{l}\text { Bignoniaceae } \\
\text { Verbenaceae } \\
\text { Euphorbiaceae }\end{array}$ & Jolivet, 1988 \\
\hline \multirow{2}{*}{$\begin{array}{l}\text { Mastosthethus } \\
\text { pantherinus }\end{array}$} & $\begin{array}{l}\text { Vernonanthura } \\
\text { (cf., V. tweediena }\end{array}$ & Asteraceae & In this study \\
\hline & Solanum (cf., S. variabile) & Solanaceae & In this study \\
\hline Megalopus sp. & $\begin{array}{l}\text { S. andigenum } \\
\text { S. tuberosum } \\
\text { S. lycopersicum }\end{array}$ & Solanaceae & Jolivet, 1977 \\
\hline
\end{tabular}

Mastostethus in Brazil. Finally, the results herein not only increase knowledge about Megalopodidae species from southwestern and western Paraná State, but also for Brazil.

\section{AUTHORS' CONTRIBUTIONS}

DMRM:Conceptualization, Methodology, Investigation, Samples, Species identification, Species photos, Writing original draft, Writing - review \& editing. GMR-M: Species identification, Writing - review \& editing. AML: Supervision, Conceptualization, Samples, Species photos, Writing - review \& editing. All the authors actively participated in the discussion of the results, they reviewed and approved the final version of the paper.

\section{CONFLICTS OF INTEREST}

Authors declare there are no conflicts of interest.

\section{REFERENCES}

Almeida, D.G.; Andrade, S.G. Viventini, B.V.; Barbosa, F.W.; Sobreira, M.F. \& Pratissoli, D. 2009. Occurrence of Faustinus sp. (Coleoptera: Curculionidae) in Southeastern Brazil tomato crops. Agronomia Colombiana, 27(3): 417-419.
Bavaresco, A. \& Pilati, G. 2005. Ocorrência de Agathomerus sellatus em tomateiro no Planalto Norte Catarinense. Agropecuária Catarinense, 18: 95-97.

Botero, J.P. 2018. Megalopodidae. In: Catálogo taxonômico da fauna do Brasil. Available: http://fauna.jbri.gov.br/fauna/faunadobrasil/124836. Access: 09/09/2020.

Carvalho, E.B. \& Monné, M.L. 2006. Agathomerus (Agathomeroides) flavomaculatus (Coleoptera, Megalopodidae, Megalopodinae): morfologia da larva e do adulto. Iheringia, Série Zoologia, 96(3):329-334.

Erber, D.\& Medvedev, L.N. 2002. Untersuchungen zur Taxonomie afrikanischer Megalopodinae mit Beschreibungen einer neuen Gattung und fünf neuer Arten (Coleoptera, Chrysomelidae). Entomologica Basiliensia, 24: 97-121.

Fidalgo, 0. \& Bononi, V.L. 1989. Técnicas de coleta, preservação e herborização de material botânico. São Paulo,: Instituto de Botânica. 62p.

Giehl, E.L.H. 2020. Flora digital do Rio Grande do Sul e de Santa Catarina. Available: https://floradigital.ufsc.br. Access: 09/09/2020.

Instituto de Terras, Cartografia e Geociências (ITCG). 2009. Formações fitogeográficas do estado do Paraná. Mapa fitogeográfico, escala 1:2.000.000.

Jolivet, P. 1977. Trophique selection in Eupoda (Coleoptera: Chrysomelidae): Megalopodinae. Bulletin Mensuel de la Société Linnéenne de Lyon, 46(9): 321-336.

Jolivet, P. 1988. Food habitats and food selection of Chrysomelidae. In: Jolivet, P.; Petitpierre, E. \& Hsiao, T.H. (Eds.). Biology of Chrysomelidae. Dordrecht, Kluwer Academy Publishers. p. 1-24.

Lawrence, J.F. \& Slipinski, A. 2014. Megalopodidae Latreille, 1802. In: Leschen. R.A.B. \& Beutel, R.G. (Eds.). Coleoptera, beetles. Morphology and systematics (Phytophaga). Handbook of Zoology. Berlin, Walter de Gruyter GmbH. p. 178-183.

Lima, C.A. 1955. Insetos do Brasil. Coleópteros.. Rio de Janeiro,Escola Nacional de Agronomia. $9^{\circ}$ tomo, $3^{\text {a }}$ parte. 289p.

Modolon, T.A.; Boff, P.; Boff, M.I.C.; Gonçalves, P.A.S. \& Miquelluti, D.J. 2013. 0 corrência de insetos em plantas de tomateiro tratadas com preparados em altas diluições. Revista de Ciências Agroveterinárias, 12(2): 155-162.

Monrós, F. 1947. Revisión de los Megalopodidae Argentinos (Col., (hrysomeloidea). Revista de la Sociedad Entomológica Argentina, 13: 150-217.

Picanço, M.; Leite, G.L.D.; Bastos, C.S.; Suinaga, F.A. \& Casali, V.W.D. 1999. Coleópteros associados ao jiloeiro (Solanum gilo Raddi). Revista Brasileira de Entomologia, 43(1/2): 131-157.

Rech, T. \& Linzmeier, A.M. 2019. Assembleia de Alticini (Coleoptera, Chrysomelidae, Galerucinae) em fragmentos florestais no sudoeste do Paraná, Brasil. Iheringia, Série Zoologia, 109: 1-9. DOI

REFLORA - Plantas do Brasil: Resgate Histórico e Herbário Virtual para 0 Conhecimento e Conservação da Flora Brasileira. 2020. Instituto de Pesquisas Jardim Botânico do Rio de Janeiro, COPPETEC - UFRJ. Available: http://floradobrasil.jbrj.gov.br/reflora/PrincipalUC/PrincipalUC.do. Access: 09/09/2020.

Rodríguez-Mirón, G.M. 2018. Checklist of the family Megalopodidae Latreille (Coleoptera: Chrysomeloidea): a synthesis of its diversity and distribution. Zootaxa, 4434(2): 265-302. DOI

Rodríguez-Mirón, G.M.; Zaragoza-Caballero, S. \& López-Pérez, S. 2017. Comparative morphology of the spermatheca in Megalopodidae (Coleoptera, Chrysomeloidea). ZooKeys, 720: 47-64. D0l

Santos, H.R. 1981. Biologia de Agathomerus sellatus (Germar, 1824) (Coleoptera, Chrysomelidae, Megalopodinae) broca do tomateiro. Revista Brasileira de Entomologia, 25(2): 165-170.

Silva, A.G.E.; Gonçalves, C.R.; Galvão, D.M.; Gonçalves, A.J.L.; Gomes, J.; Silva, M.N. \& Simoni, L. 1968. Quarto catálogo dos insetos que vivem nas plantas 
do Brasil, seus parasitas e predadores. Rio de Janeiro, Ministério da Agricultura, Departamento de Defesa e Inspeção Agropecuária. parte 2, tomo 1.

Tella, R. 1952. Contribuição para o conhecimento do Agathomerus sellatus Germ. (Col., Megalopodidae). Revista da Agricultura, 27: 373-376.
Townes, H. 1972. A light-weight malaise trap. Entomological News, 83(9): 239-247.

Vernalha, M.M.; Rocha, M.A.L.; Gabardo, J.C. \& Silva, R.P. 1968. Principais pragas das plantas cultivadas no Estado do Paraná. Curitiba, Diretório Acadêmico Lycio Vellozo. 264p. 